\title{
BLUE SKY RESEARCH
}

\section{Discovery can’t afford to knap.}

\section{BY IAN STEWART}

$\mathrm{T}$ he sun beat down like a hammer. Stoneseeker scoured the base of the cliff, looking for rock samples to take back to the elders. It was his first solo exploration, and his brief was simple: find more flint. The chief had relieved him of hunting duties, providing food and a waterskin. In return, the young man had promised to seek out a new source of the dense black flint that could be knapped into knives, arrowheads and spearheads, for the old sources were running out.

He tracked speckled seams of dark stones as they wove along white cliffs, but the quality of the flint started out poor and steadily got worse. Eventually the seams ran out altogether, mainly because the cliffs ran out. $\mathrm{He}$ could not return to the tribe empty-handed, not when it had provided so generously for his expedition. He camped for the night, making a fire to scare away predators.

Next morning, he walked across shattered rock and gravel, heading for a distant hill. If not flint, perhaps there would be obsidian! The glassy material was hard to work, but its shards were sharp and the edge lasted longer.

No flint, no obsidian. But he did find an outcrop of rock, of a kind he had never seen before; almost the colour of the sky, but tinged with green. Interesting. Curiosity aroused, he put a few lumps in his shoulder-bag.

Flint, he reminded himself, and walked on. Two days later he gave up, and turned back to face the tribe's wrath.

The chief towered over him, splendid in eagle-feather robes. Stoneseeker trembled. "I failed, Bearkiller," he confessed. "I found no flint."

"That was not your promise when you were relieved of mammoth-hunting duties and given food caught by others!"

I promised to look, not to find, Stoneseeker thought. But it was unwise to contradict the chief.

"Don't hunt, don't eat," Snakebite the shaman jeered.

"I did find these," Stoneseeker said humbly. Bearkiller took the strange bluish stones, and passed them to Blademaker. The flintknapper placed one on his thigh-pad and struck it with a hammer-stone. It crumbled into fragments.

"Won't take an edge," he complained. "Useless!"

Stoneseeker, still intrigued by the strange stones, gave utterance to a thought that had

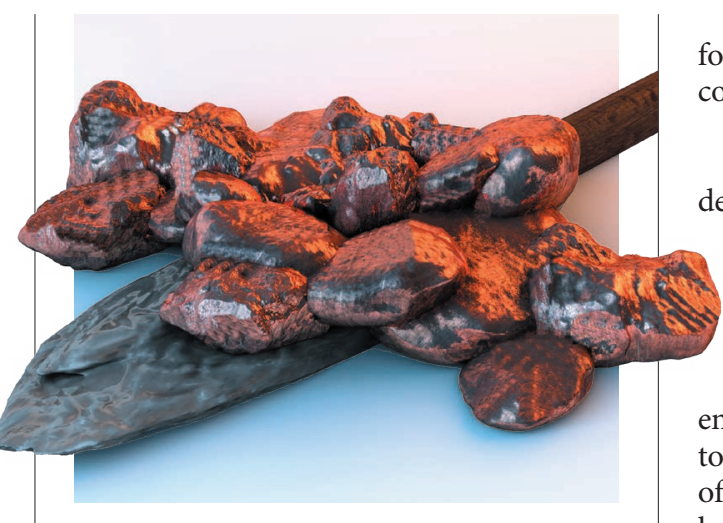

The real answer was trapped prey, for food, but what the chief expected was the conventional folk-wisdom.

"Curiosity," Stoneseeker whispered.

"Curiosity killed the cat!" the shaman declaimed.

"You mean well, youngster," said the chief. "But the tribe can't squander precious food to let you waste good hunting-time, merely to satisfy your curiosity." He raised his eyes to the heavens. "We need practical ideas. As well as try to find out why your stones are the colour of the sky!" The other elders howled with laughter. "You can't tell us what you will

been growing in his mind. "Bearkiller, I seek a boon."

"A boon? For failure?"

"I am Stoneseeker! I seek stones. I found stones. Er - just not flint."

"You found wrong stones!" roared Bearkiller. "I sent you for flint!"

"Well, yes ... but I found these stones instead, great chief, and I'm wondering whether it's worth investigating them. They have the colour of the sky. Such marvels could have powers undreamt of!"

Blademaker sneered. "Can your skystones make a spear? A knife? Even a rudimentary hide-scraper?" He picked up the fragments, let them fall through his fingers. "They don't even make serviceable hammerstones!” He spat. "Useless!"

"How do you plan to investigate the stones?" Bearkiller asked quietly.

"Uh - I haven't really got that far, great chief. Drop them in water? Throw them at hares? Leave one lying in the moonlight? Rub them with -"

"And what do you propose to find?"

"I have no idea."

"Then what use are they?"

Stoneseeker sought a helpful analogy. "Great chief: what use is a newborn baby?"

"Not my department. Call the midwife."

"Don't listen to the idiot!" Mammothstabber yelled. "He's just trying to con us into feeding him while he weasels out of the hunt!"

"Don't hunt, don't eat," the shaman repeated.

Bearkiller stroked his impressive beard thoughtfully. "Half a day's walk from here is a tar-pit," he said enigmatically. "What do we find there, Stoneseeker?"

"Lions," Stoneseeker mumbled. He could see where this was going. "Dead ones."

"And what made them walk into the tar to die?" investigate. You can't tell us what you will find. You don't know what you're doing."

If I knew beforehand what I'd discover, there'd be no point in trying to discover it, Stoneseeker thought, but remained silent.

Stoneseeker showed the sky-stones to Foxfoot, who made pots. "Heat does strange things to colours," she mused. "If I grind some of these they might just work as glaze. Or the heat might make the stones stronger. I've built a new kiln, the hottest yet! I'll heat them overnight."

Next morning, when Foxfoot looked for the stones in the kiln, there was nothing but grey ash. Raking it out, something strange caught her eye. She picked it up and wiped away the ash. It was a lumpy tangle of reddish material. Some bits glistened in the sunlight.

They took it to show Bearkiller.

"I told you not to investigate further."

"We did it in our spare time, great chief."

"People who eat at the tribe's expense but produce nothing should not have spare time." He glared at Stoneseeker. "You're going to ask me to reverse my decision, aren't you? Just because you've found something you don't understand." He turned the irregular mass of - something - in his hand. "I'll ask the expert. Blademaker!"

The flint-knapper rushed over.

"What do you think of this stuff?"

Blademaker took the strange lumpy material and grunted unhappily. It bent easily in his hands. "Too soft. It will never replace the flint spearhead! Useless!"

Bearkiller nodded. And threw it away. -

Ian Stewart's latest SF novel is Rock Star. He is sole winner of the Bloody Stupid Johnson award for Innovative Uses of Mathematics, and an honorary wizard of Unseen University. 